\title{
Ground-Water Models of the Alluvial and Sparta Aquifers: Management Tools for a Sustainable Resource
}

\section{Introduction}

Arkansas is the fourth largest user of ground water in the United States. The Mississippi River Valley alluvial aquifer (alluvial aquifer) is a water-bearing assemblage of gravels and sands that underlies most of eastern Arkansas and several adjacent States. Ground-water withdrawals have caused cones of depression to develop in the alluvial aquifer water-level surface, some as much as 100 feet deep. Long-term water-level measurements show an average annual decline of 1 foot per year in some areas. The Sparta aquifer is largely a confined aquifer of regional importance that comprises a sequence of unconsolidated sand, silt, and clay units. Several large cones of depression have developed in the Sparta aquifer, causing hydraulic heads to drop below the top of the formation in parts of central and southern Arkansas and several areas in north-central Louisiana.

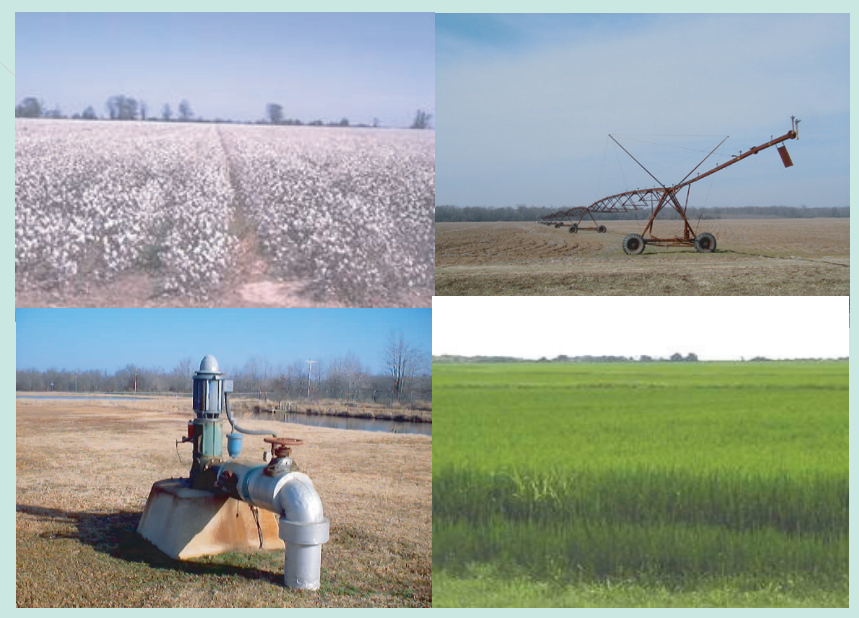

Several counties in the Grand Prairie area and south Arkansas have been designated Critical Ground-Water Areas (areas where alluvial aquifer water levels dropped below 50 percent of the original saturated thickness or below the top of the Sparta Sand formation) by the Arkansas Soil and Water Conservation Commission (ASWCC). The expansion of the cones of depression and the consistent water-level declines indicate that ground-water withdrawals are occurring at a rate that is greater than the sustainable yield of the aquifer.

\section{Ground-Water Models}

For many years, the ASWCC has worked with the U.S. Geological Survey (USGS) and other agencies in the develop- ment of ground-water flow models to be used as management tools to determine the sustainability of the water resource. Ground-water flow models of two areas of the alluvial aquifer (north alluvial and south alluvial_-divided by the Arkansas River) and the Sparta aquifer were developed for eastern Arkansas and parts of northern Louisiana and adjacent States (Reed, 2003; Stanton and Clark, 2003; McKee and Clark, 2003).

The flow models showed that continued ground-water withdrawals at 1997 rates for the alluvial aquifer and 1990-97 rates for the Sparta aquifer could not be sustained indefinitely without causing water levels to decline below 50 percent of the original saturated thickness of the alluvial aquifer or below the top of the Sparta Sand formation. To develop estimates of withdrawal rates that could be sustained relative to the constraints of critical ground-water area designation, conjunctive-use optimization modeling was applied to the flow models (Czarnecki and others, 2003a,b; McKee and others, 2004). An optimization model calculates the maximum sustainable yield from wells and rivers, while maintaining simulated water levels and streamflows at or above minimum specified limits or constraints.

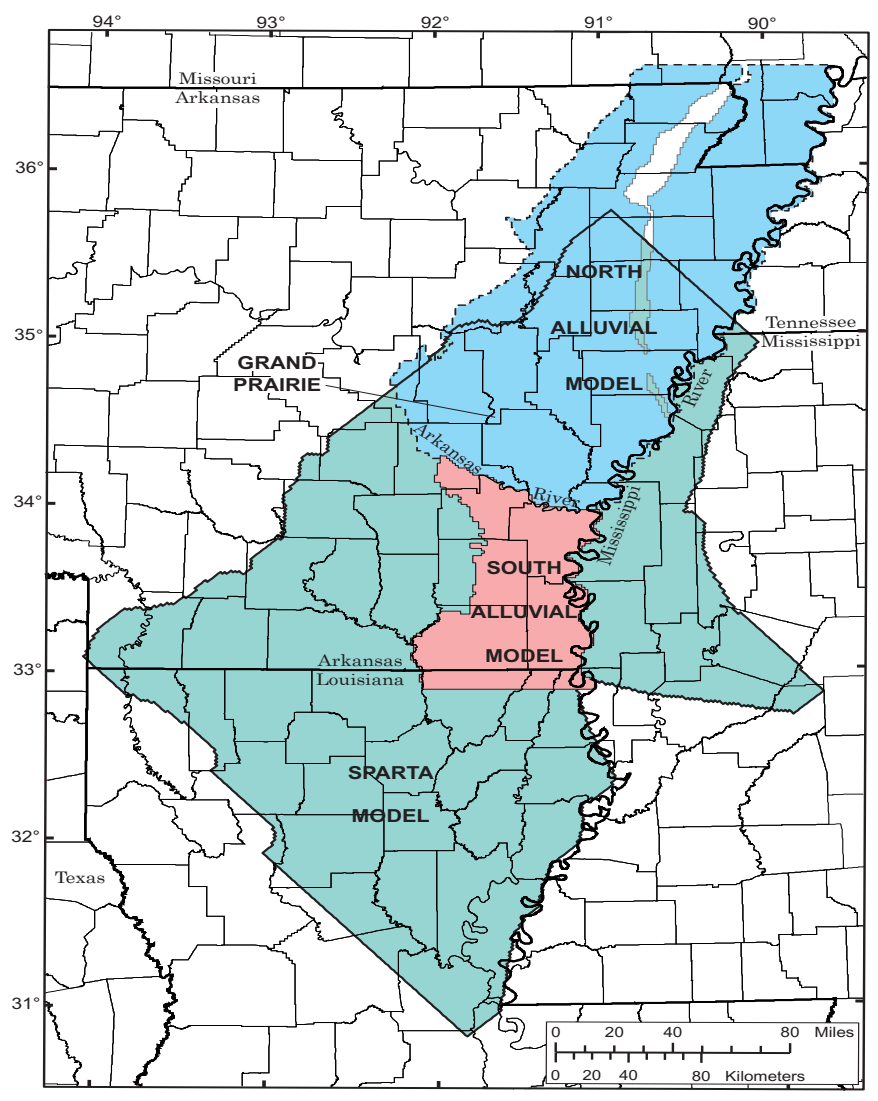


Sustainable yield is the rate at which water can be withdrawn indefinitely from ground- and surface-water sources without violating specified constraints. This rate is calculated through the use of a conjunctive-use optimization model. Sustainable yield is dependent on upper limits of specified withdrawal rates for wells and rivers and can vary given various imposed constraints. Demand is the amount of ground water used or withdrawn during the period. Unmet demand is the difference between a desired withdrawal rate (demand) and the sustainable yield. Sustainable yield from rivers represents a potential source of water that could supplement ground water.

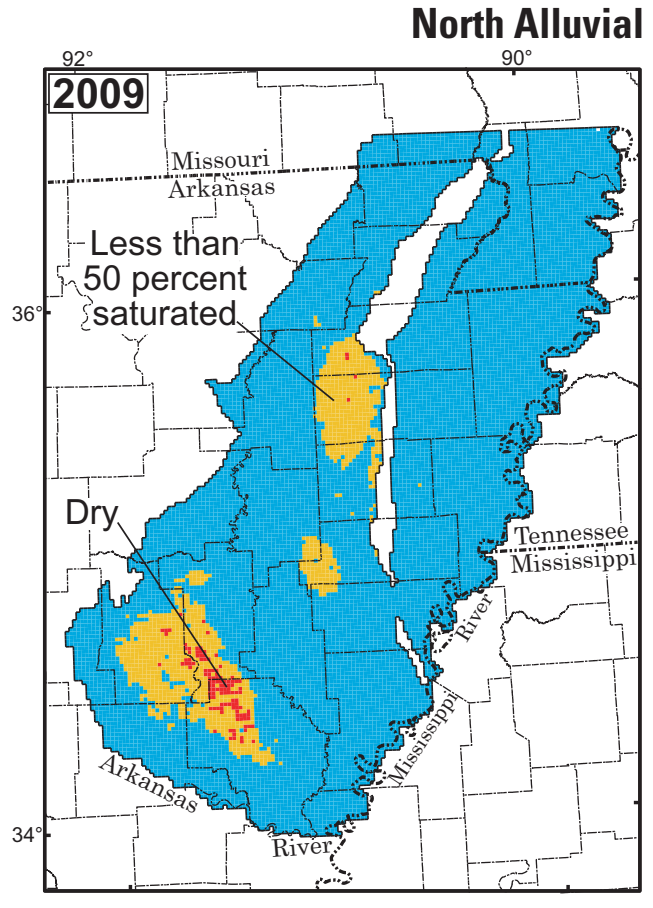

118 square miles of dry aquifer 1,481 square miles less than 50 percent saturated

\section{North Alluvial Model}

The alluvial flow model in northeastern Arkansas was used to predict ground-water flow for a 50-year period from 1998-2049 with different hypothetical pumping scenarios. If pumping remains at 1997 rates (635.7 million cubic feet per day $\left(\mathrm{Mft}^{3} / \mathrm{d}\right)$, large simulated water-level declines occur in two areas of the aquifer, one in the Grand Prairie area between the Arkansas and White Rivers and the other west of Crowleys Ridge along the Cache River. Simulations show that by 2009 over 100 square miles $\left(\mathrm{mi}^{2}\right)$ of the alluvial aquifer could be dry (demand exceeding sustainable yield) with about $400 \mathrm{mi}^{2}$ of the aquifer going dry by 2049. Given imposed constraints, ground-water sustainable yield is 360.3 $\mathrm{Mft}^{3} / \mathrm{d}-57$ percent of the $635.7 \mathrm{Mft}^{3} / \mathrm{d}^{2}$ demand in 1997 . This unmet demand of $275.5 \mathrm{Mft}^{3} / \mathrm{d}$ of ground water could be obtained from large sustainable surface-water withdrawals. Total sustainable yield from all rivers combined was 12,806 $\mathrm{Mft}^{3} / \mathrm{d}$, which represents a substantial source for supplementing ground water to meet the total water demand.

\begin{tabular}{|c|c|c|c|}
\hline $\begin{array}{c}\text { Sustainable } \\
\text { yield from } \\
\text { ground water } \\
\left(\mathbf{M f t}^{3} / \mathbf{d}\right)\end{array}$ & $\begin{array}{c}\text { Ground- } \\
\text { water } \\
\mathbf{d e m a n d} \\
\left(\mathbf{M f t}^{3} / \mathbf{d}\right)\end{array}$ & $\begin{array}{c}\text { Unmet } \\
\text { demand for } \\
\text { ground water } \\
(\mathbf{M f t} / \mathbf{d})\end{array}$ & $\begin{array}{c}\text { Sustainable } \\
\text { yield from } \\
\text { rivers } \\
\left(\mathbf{M f t}^{3} / \mathbf{d}\right)\end{array}$ \\
\hline 360.3 & 635.7 & 275.5 & 12,806 \\
\hline
\end{tabular}

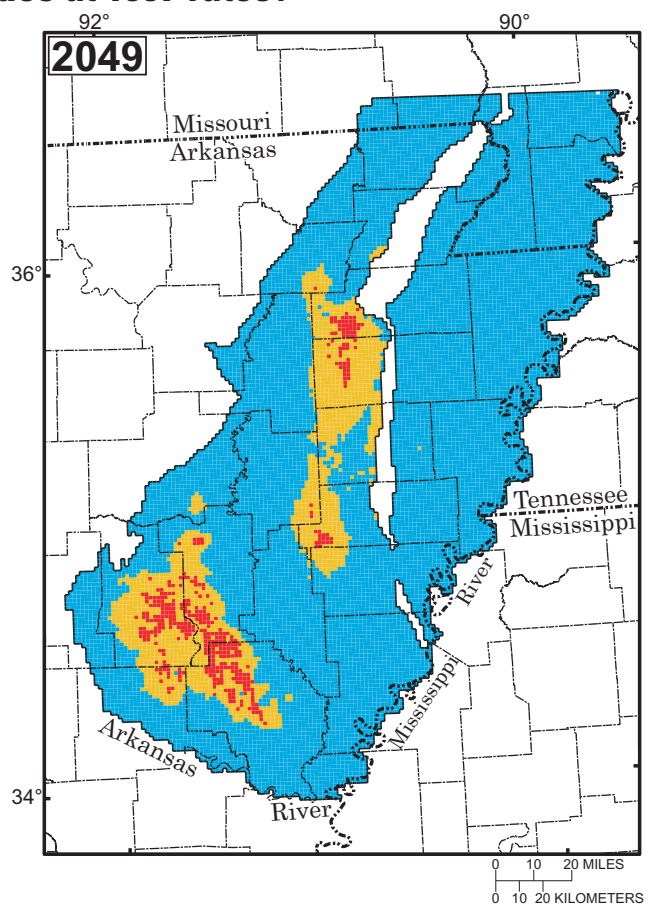

401 square miles of dry aquifer 2,195 square miles less than 50 percent saturated saturated

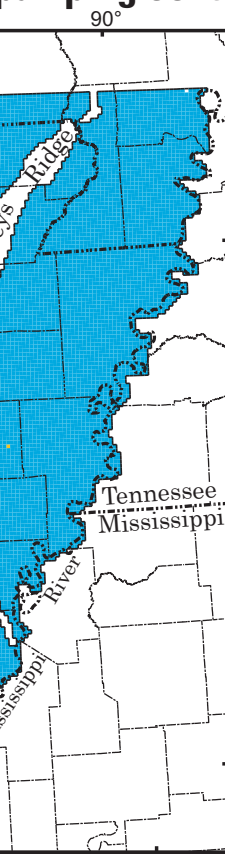

$$
\begin{aligned}
& \text { dry aquifer } \\
& \text { than } 50 \text { percent }
\end{aligned}
$$

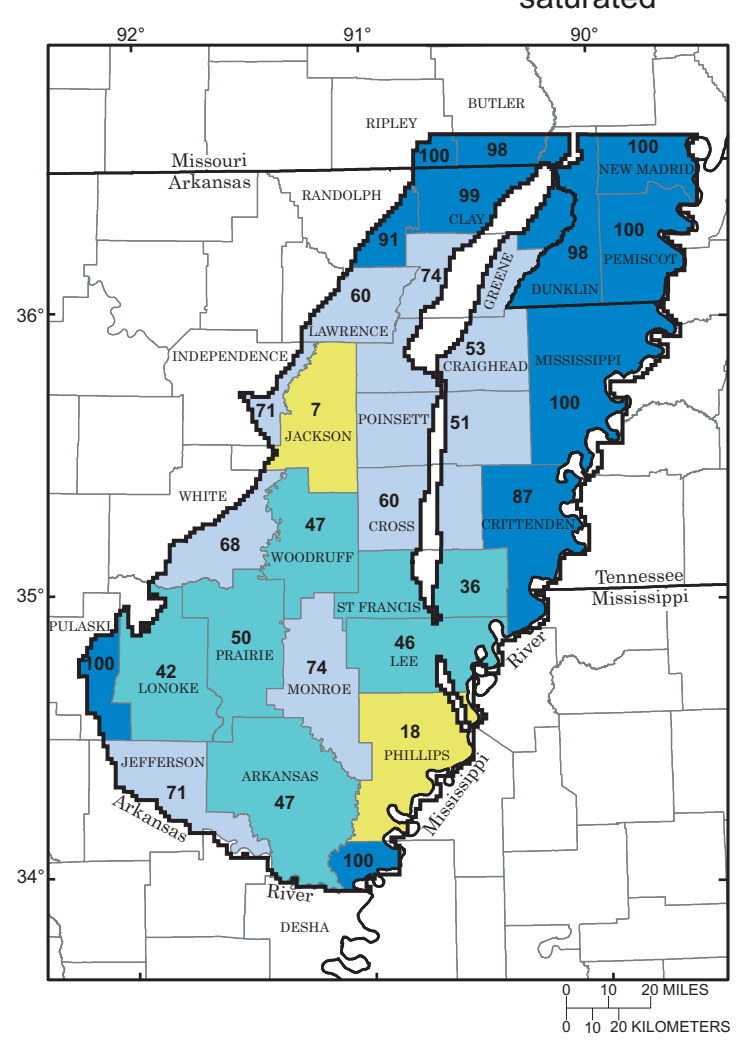

Percentage of 1997 withdrawal from alluvial aquifer that is sustainable by county (north alluvial model) 


\section{South Alluvial Model - What happens if pumping continues at 1997 rates?}

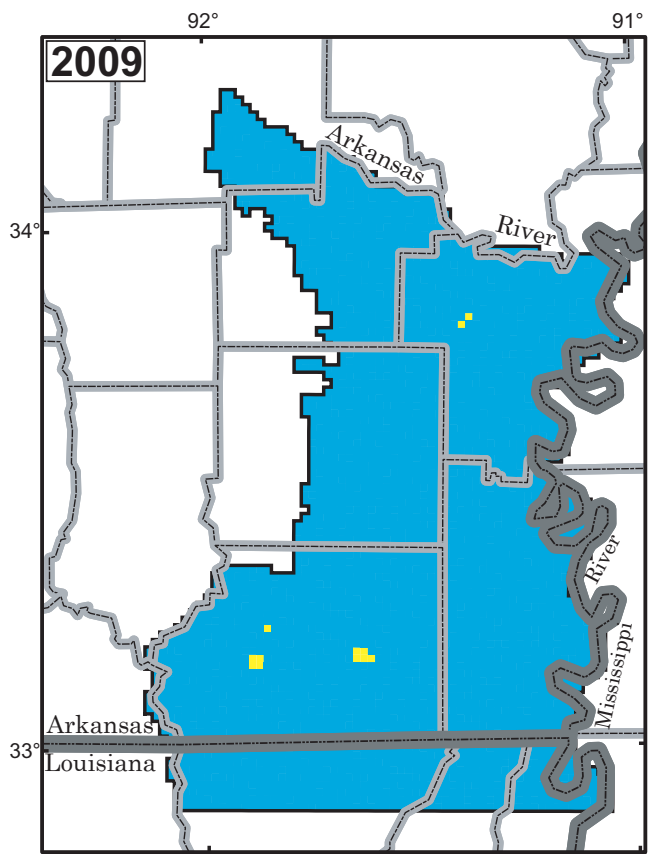

0 square miles of dry aquifer 12 square miles less than 50 percent saturated

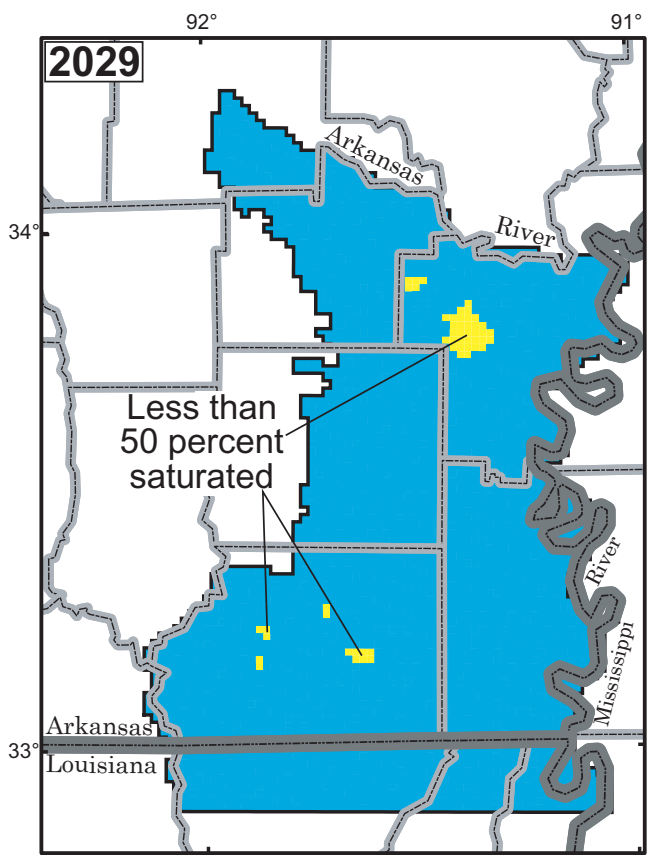

0 square miles of dry aquifer 52 square miles less than 50 percent saturated

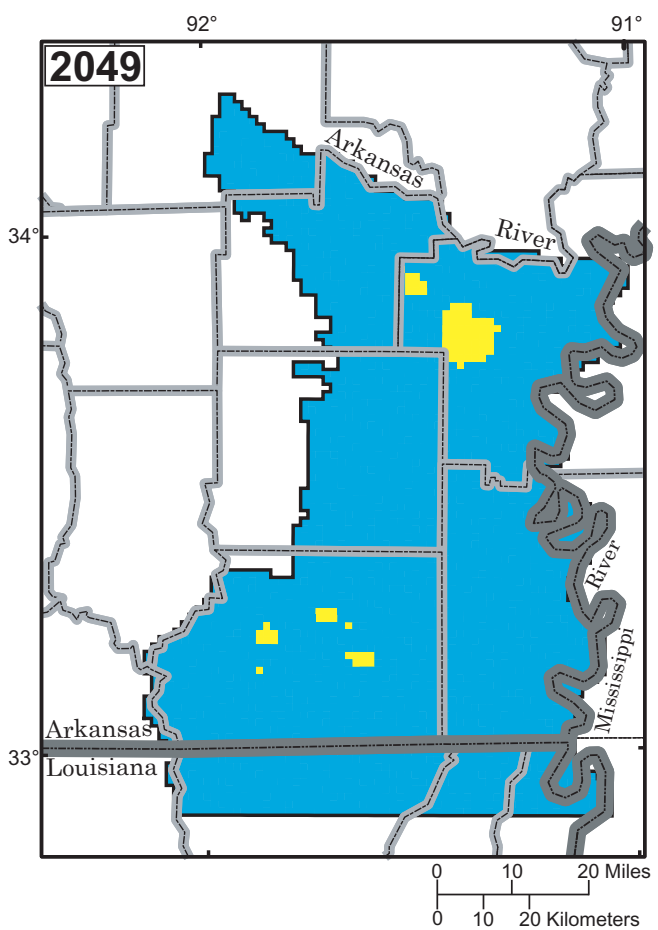

0 square miles of dry aquifer 81 square miles less than 50 percent saturated

\section{South Alluvial Model}

The flow model for the alluvial aquifer in southeastern Arkansas was used to predict ground-water flow for a 50-year period from 1998-2049 with different hypothetical pumping scenarios. If pumping remains at 1997 rates $\left(73.5 \mathrm{Mft}^{3} / \mathrm{d}\right)$, an area centered in Desha County and two areas in Ashley County show simulated water levels dropping below 50 percent of the saturated thickness of the alluvial aquifer by 2009. Simulated water levels for 2029 and 2049 indicate enlargement and deepening of these areas and up to $81 \mathrm{mi}^{2}$ where the aquifer drops below 50 percent of the saturated thickness, although no areas of the aquifer go dry. Given imposed constraints, ground-water sustainable yield is $70.3 \mathrm{Mft}^{3} / \mathrm{d}-96$ percent of the demand of $73.5 \mathrm{Mft}^{3} / \mathrm{d}$. Unmet demand for the model area is $3.3 \mathrm{Mft}^{3} / \mathrm{d}$. Total sustainable yield from the rivers is about $4,918 \mathrm{Mft}^{3} / \mathrm{d}$, or about 6,700 percent of the amount of ground water withdrawn in 1997, which represents a substantial source for supplementing ground water to meet the total water demand.

\begin{tabular}{|c|c|c|c|}
\hline $\begin{array}{c}\text { Sustainable } \\
\text { yield from } \\
\text { ground water } \\
\left(\mathbf{M f t}^{3} / \mathbf{d}\right)\end{array}$ & $\begin{array}{c}\text { Ground- } \\
\text { water } \\
\text { demand } \\
\text { (Mft }\end{array}$ & $\begin{array}{c}\text { Unmet } \\
\text { demand for } \\
\text { ground water } \\
\left(\mathbf{M f t}^{3} / \mathbf{d}\right)\end{array}$ & $\begin{array}{c}\text { Sustainable } \\
\text { vield from } \\
\text { rivers } \\
\left(\mathbf{M f t}^{3} / \mathbf{d}\right)\end{array}$ \\
\hline 70.3 & 73.5 & 3.3 & 4,918 \\
\hline
\end{tabular}

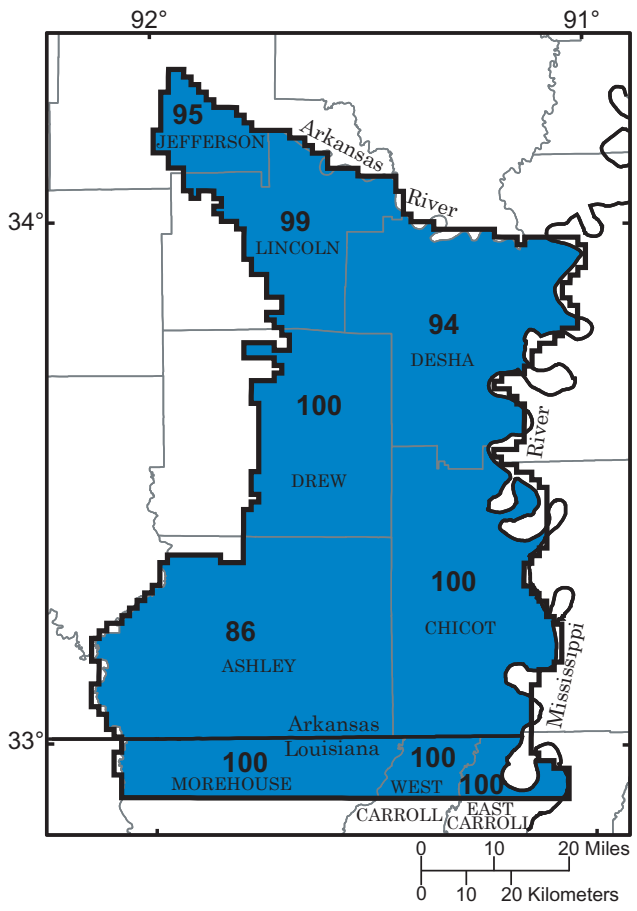

Percentage of 1997 withdrawal from alluvial aquifer that is sustainable by county (south alluvial model) 


\section{Sparta Model}

The Sparta flow model was used to predict the effects of three hypothetical withdrawal scenarios on water levels over a 30-year period from 1998-2027. In one scenario, withdrawal rates $\left(30.6 \mathrm{Mft}^{3} / \mathrm{d}\right)$ from 1990-97 were held constant for 30 years from 1998-2027 and simulated water levels decreased by 10 feet in El Dorado and 17 feet in Pine Bluff, Arkansas. Through 2027, simulated water levels continue to decline in the center of cones of depression in areas of El Dorado, Pine Bluff, Magnolia in Arkansas, and in Monroe, Louisiana. Cones of depression continue to deepen and expand, and areas where water levels have dropped below the top of the Sparta Sand formation grow to 1,787 $\mathrm{mi}^{2}$ in size in Arkansas and 2,821 $\mathrm{mi}^{2}$ in Louisiana by 2027. Given imposed constraints, ground-water sustainable yield in Arkansas and Louisiana is $11.9 \mathrm{Mft}^{3} / \mathrm{d}-39$ percent of the total ground-water demand of $30.6 \mathrm{Mft}^{3} / \mathrm{d}$. The remainder, $18.8 \mathrm{Mft}^{3} / \mathrm{d}$, is defined as unmet demand that could be obtained from the $5,396 \mathrm{Mft}^{3} / \mathrm{d}$ sustainable yields from rivers.

\begin{tabular}{|c|c|c|c|}
\hline $\begin{array}{c}\text { Sustainable } \\
\text { yield from } \\
\text { ground water } \\
\left(\mathbf{M f t}^{3} / \mathbf{d}\right)\end{array}$ & $\begin{array}{c}\text { Ground- } \\
\text { water } \\
\text { demand } \\
\left(\mathbf{M f t}^{3} / \mathbf{d}\right)\end{array}$ & $\begin{array}{c}\text { Unmet } \\
\text { demand for } \\
\text { ground water } \\
\left(\mathbf{M f t}^{3} / \mathbf{d}\right)\end{array}$ & $\begin{array}{c}\text { Sustainable } \\
\text { yield from } \\
\text { river } \\
\left(\mathbf{M f t}^{3} / \mathbf{d}\right)\end{array}$ \\
\hline 11.9 & 30.6 & 18.8 & 5,396 \\
\hline
\end{tabular}

\section{References}

Czarnecki, J.B., Clark, B.R., and Stanton, G.P., 2003a, Conjunctive-use optimization model of the Mississippi River Valley alluvial aquifer of southeastern Arkansas: U.S. Geological Survey Water-Resources Investigations Report 03-4233, 26 p.

Czarnecki, J.B., Clark, B.R., and Reed, T.B., 2003b, Conjunctive-use optimization model of the Mississippi River Valley alluvial aquifer of northeastern Arkansas: U.S. Geological Survey Water-Resources Investigations Report 03-4230, 29 p.

McKee, P.W., and Clark, B.R., 2003, Development and calibration of a ground-water flow model for the Sparta aquifer of southeastern Arkansas and north-central Louisiana and simulated response to withdrawals, 1998-2027: U.S. Geological Survey Water-Resources Investigations Report 03-4132, 71 p.

McKee, P.W., Clark, B.R., and Czarnecki, J.B., 2004, Conjunctive-use optimization and sustainable-yield estimation for the Sparta aquifer of southeastern Arkansas and north-central Louisiana: U.S. Geological Survey Water-Resources Investigations Report 03-4231, 30 p.

Reed, T.B., 2003, Recalibration of a ground-water flow model of the Mississippi River Valley alluvial aquifer of northeastern Arkansas, 1918-1998, with simulations of water levels caused by projected ground-water withdrawals through 2049: U.S. Geological Survey Water-Resources Investigations Report 03-4109, 58 p.

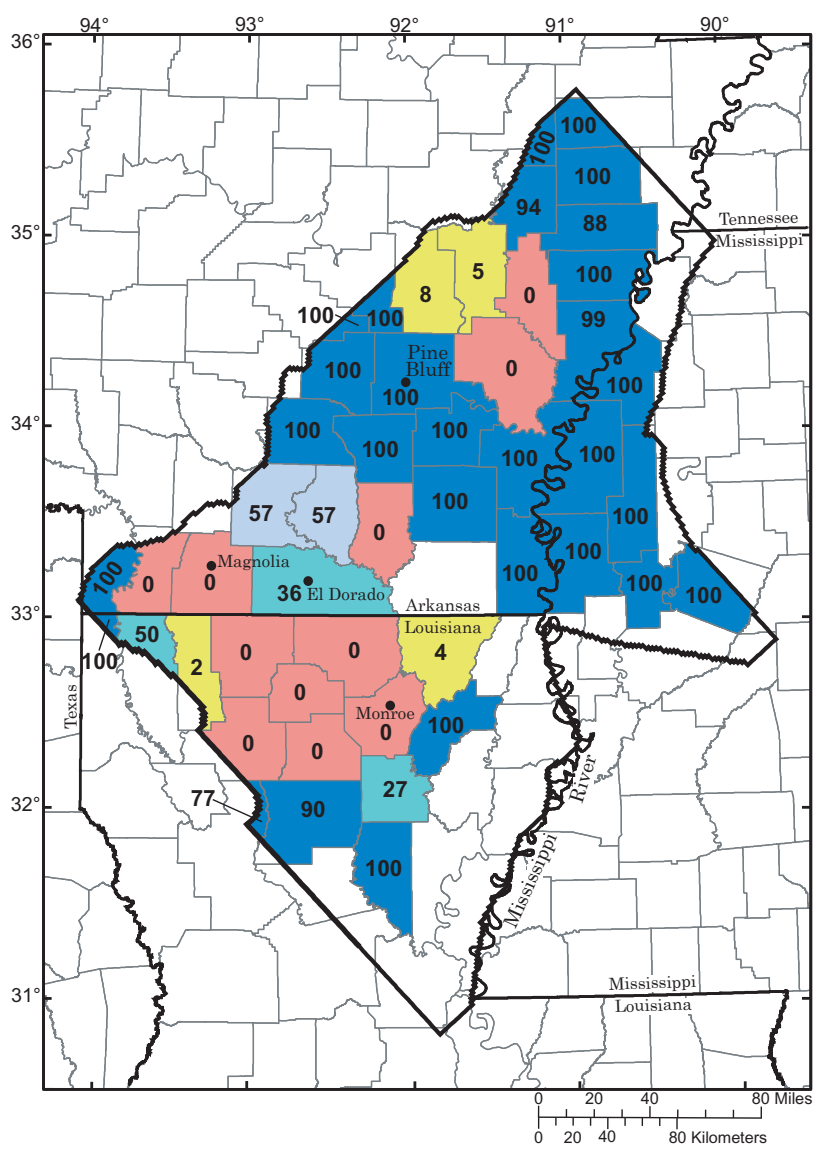

Percentage of 1990-97 withdrawal from Sparta aquifer that is sustainable by county (Sparta model).

Stanton, G.P. and Clark, B.R., 2003, Recalibration of a ground-water flow model of the Mississippi River Valley alluvial aquifer in southeastern Arkansas, 1918-1998, with simulations of hydraulic heads caused by projected groundwater withdrawals through 2049: U.S. Geological Survey Water-Resources Investigations Report 03-4232, 48 p.

- David A. Freiwald

Any use of trade, product, or firm names is for descriptive purposes only and does not imply endorsement by the U.S. Government.

\section{Information on technical reports and hydrologic data related to this study can be obtained from:}

Director

U.S. Geological Survey

Arkansas Water Science Center

401 Hardin Road

Little Rock, AR 72211

Email: dc_ar@usgs.gov

Phone: (501) 228-3600

FAX: (501) 228-3601

World Wide Web: http://ar.water.usgs.gov/ 